\title{
HISTORY OF DEVELOPMENT OF AZERBAIJANI REAL ESTATE LEGISLATION (20-50S OF XX CENTURY)
}

\author{
DADASHOV Emin Teyyub - PhD in law Senior researcher at the Institute of \\ Law and Human Rights of the Azerbaijan National Academy of Sciences \\ DOI:10.32782/NP.2020.2.23
}

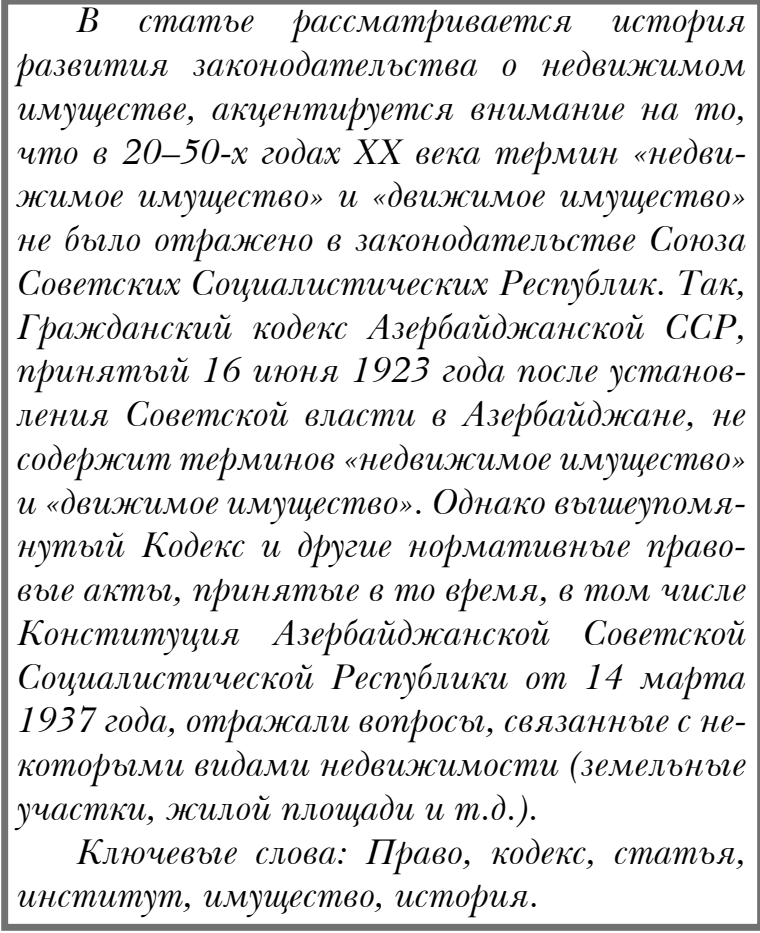

After the formation of the USSR in December 1922, the legal history of Azerbaijan, including the legal history of real estate, began to develop as an integral part of the legal history of the USSR. Looking at the history of the development of real estate legislation, we see that the division of property into movable and immovable property has not existed for a long time in the legislation of the Union of Soviet Socialist Republics. Thus, the Civil Code of the Azerbaijan SSR, consisting of 524 articles, adopted at the third session of the second convocation of the Central Executive Committee of Azerbaijan on June 16, 1923 and entered into force on September 8, 1923, does not contain the terms movable or immovable things or movable and immovable property [1]. However, the mentioned Code and other normative legal acts reflected issues related to some types of real estate (land, residential areas, etc.).

Pursuant to Article 71 of the Civil Code of 16 June 1923, contracts for the allocation of urban lands for construction between communal departments, cooperatives or other legal entities, as well as between individual citizens for stone buildings were concluded for 49 years and 20 years for other buildings.

Article 71 of the Civil Code also contained two notes with the following content:

"Note 1. A contract on the right of construction may be concluded for a plot of land which is not directly intended for construction, but which provides economic services to it.

Note 2. The rules specified in Articles 71-84 of the Civil Code (the second chapter of this Code, entitled "Construction Law", covered Articles 71-84), shall also apply to contracts concluded for land plots outside the city. Contracts for the construction of land plots in these areas are concluded by the land and other local authorities with the relevant land plots at their disposal. The rights and responsibilities set out in Articles 71-84 of the Civil Code for communal departments, if necessary, belong to the above-mentioned local authorities".

Article 72 of the Civil Code stated that a contract for the right to build must be notarized in order not to be considered invalid. 


\section{Цивільне, підприсмницьке, господарське та трудове право}

By a decision of 6 May 1926, the wording of Article 71 of the Civil Code was amended and the term of contracts for the transfer of urban land for construction between the above-mentioned persons was extended to 60 years for stone buildings and 40 years for other buildings [2].

By the Decision of November 27, 1926, the notes of Article 71 of the Civil Code remained in force and the text was changed again and given in the following edition:

"Contracts for the transfer of urban land for construction are concluded with public general service departments, cooperatives and other legal entities, as well as with individual citizens. Such contracts last up to 60 years for stone buildings and 40 years for timber and other buildings.

If land plots, workers' apartments are given for construction and buildings are rebuilt, construction contracts must be concluded for the above mentioned periods (60 and 40 years). If the construction of buildings is completed or they are restored, then contracts for the right to build cannot be concluded for less than twothirds of the maximum period (less than 50 or 27 years)".

The new version of Article 73 of the Civil Code of the Azerbaijan SSR of June 16, 1923, given by the order dated November 27, 1926, stated that when land plots were given for the construction of workers' apartments, the construction period was up to 2 years and the completion period was while up to 4 years. For organizations that aim to build settlements and a group of buildings, the construction completion period is extended to eight years [3].

The Decree of October 2, 1927 added a third note to Article 71 of the Civil Code in this context: "Land plots for construction of buildings by workers and citizens' housing cooperatives are given to them at their choice or for the period specified in the contract on the right of construction, or for an indefinite period. The buildings built on the land plots given to these companies for indefinite use belong to them with the right of ownership.

The right of indefinite use of land is inseparable from the right of ownership of the building, and when the right of ownership of the building is revoked, it is also revoked. In the event of the destruction of a building, the right to indefinite use of the land shall be retained, provided that the worker or the general housing cooperative has built a new building no later than three years from the date of the demolition of the previous one" [4].

By the Decision of December 10, 1927, the notes of Article 71 of the Civil Code remained in force and the text was changed again and given in the following edition:

"Contracts for the allocation of urban land for construction are concluded with cooperatives and other legal entities, as well as individual citizens for up to 65 years for stone buildings, up to 60 years for mixed buildings and up to 50 years for timber buildings.

In case of transfer of land plots for construction of workers' apartments and reconstruction of the building, the contracts on the right of construction must be concluded for the abovementioned periods ( 65,60 and 50 years). If the buildings are built, completed or restored, the contracts on the right of construction may not be concluded for less than two-thirds of the upper limits, ie for 44, 40 and 34 years" [5].

Article 76 of the Civil Code stated: "Residential buildings built by housing construction cooperatives (workers and citizens) on lands given to them for permanent use are exempt from construction tax for up to 3 years after construction, and after the expiration of this period, if the usable area of the building is not less than $75 \%$ of the total area of the building, the tax shall be levied not exceeding $50 \%$ of the tax payable within 30 years".

On April 17, 1928, the Council of People's Commissars of the USSR adopted a Resolution "On measures to expand housing construction at the expense of private investment" consisting of 21 articles. According to Article 7 of the same Decree, the validity period of contracts for land plots for the construction of large apartment houses was set at 80 years for stone, metal, concrete and mixed houses, and 60 years for timber buildings.

Guided by the Resolution of the Council of People's Commissars of the USSR dated April 17, 1928, on February 16, 1929, the following note was added to Article 71 and a note to Article 152 of the Civil Code of the Azerbaijan SSR with the following content: 
"Note 4 of Article 71 of the Civil Code: "Validity of contracts concluded for land plots for the construction of large apartment houses provided for in the decision of the USSR Council of People's Commissars of April 17, 1928 "On measures to expand housing construction at the expense of private investment", is defined 80 years for stone, metal, concrete and prefabricated houses, and 60 years for timber buildings".

Note of Article 152 of the Civil Code: "According to the Decision of the USSR Council of People's Commissars "On measures to expand housing construction at the expense of private investment" dated April 17, 1928, Contracts for the lease of residential and non-residential apartments to private individuals (legal and natural) in the houses under construction may be stipulated as a period of rent, in the form of a one-time rent when renting an apartment, or in both the first and second forms" [6].

Note 2 added to Article 155 of the Civil Code by the Decree of December 13, 1929 considered the lease of living space in the houses of state institutions and enterprises, as well as in houses built by state institutions and enterprises only on other grounds of contracts concluded for a certain period [7].

In general, the lease of residential real estate was regulated in the Civil Code of the Azerbaijan SSR of 1923 not in the form of an independent contract, but within the lease of property (Articles 152-179 of the Civil Code of 1923). However, the lease of living space, which is an integral part of the housing legislation, developed independently and gradually lost its relevance to the provisions of the Civil Code. Thus, the lease of living space was regulated in detail by a separate normative act - by the Resolution of the Central Executive Committee of the USSR and the Council of People's Commissars of January 4, 1928 "On Housing Policy".

Provisions related to the administrative relocation of certain categories of the population from residential buildings were set out in Article 172 of the Civil Code. This article is given in the new edition by the Decision of January 18, 1930 as follows: "Administrative relocation of residential buildings is allowed only in cases specifically provided by law, as well as in case of sale of residential buildings owned by non-working people by open auction or other means provided by law for non-payment of state or local taxes and duties; in this case, the right to own the dwelling occupied by the former owner of the construction, as well as his family members and dependents, passes to the buyer, provided that the family members and dependents of the former owner of the construction are not laborers. If this is the case, both the former owner of the apartment building and his family members must be relocated administratively".

Non-municipal residential buildings could be the subject of a sale if the buyer, his wife (husband) and minor children had two or more properties (the house and adjacent residential and service buildings were considered property) as a result of the sale; sold on behalf of the seller, his wife (husband) and minor children for not more than one property for 3 years.

The purchase and sale of the buildings had to be notarized and then registered with the relevant local economic department (communal department) in order to be valid.

Article 6 of the USSR Constitution, adopted on December 5, 1936, consisting of 146 articles and going down in history as the «Stalin Constitution», stated that the main housing stock of cities and industrial settlements is state property, ie national wealth.

However, Article 10 of the Constitution of 5 December 1936 stated that citizens could own a dwelling house. That is, the fact that a residential house, which is residential real estate, is privately owned by citizens was reflected in the Constitution.

After the entry into force of the USSR Constitution on December 5, 1936, the Constitution of the Azerbaijan Soviet Socialist Republic, consisting of 14 chapters and 154 articles, was approved by the decision of the IX All-Azerbaijani Extraordinary Congress of Soviets on March 14, 1937. Articles 6 and 10 of the Constitution, which also contained provisions related to land and residential real estate, stated:

"Article 6. Land, subsoil, water, forests, factories, mines, mining plants, railways, water and air transport, banks, communications, large state-owned agricultural enterprises (state farms, machine-tractor stations, etc.), as 


\section{Цивільне, підприсмницьке, господарське та трудове право}

well as in cities and industrial areas, communal enterprises and the main housing stock are state property, ie all public property.

Article 10. The right of citizens to their own income and savings, housing and auxiliary households, household items and equipment, personal consumption and comfort items, as well as the right of citizens to inherit personal property shall be protected by law".

After the entry into force of the new Constitution, a number of measures were taken in the field of residential real estate.The Resolution of the Central Executive Committee of the USSR and the Council of People's Commissars of October 17, 1937, "On the Protection of Housing and Improvement of Housing in Cities", which consisted of 36 articles, provided for the liquidation of housing cooperatives. It was allowed to maintain housing cooperatives, for which all debts on bank loans received from the state were repaid within the period established by law. In accordance with the Decision of the Central Executive Committee of the USSR and the Council of People's Commissars of October 17, 1937, the following persons had the right to use the apartment building independently:

$\ddot{u} \quad$ Buyers of residential buildings, their family members and those under their care in accordance with the orders of the housing department;

$\ddot{u} \quad$ persons living in houses belonging to them on the basis of the right of private property, their family members and their dependents;

$\ddot{u}$ persons living in houses provided for life use, their family members and their dependents;

$\ddot{u}$ shareholders-members of construction cooperatives, their family members and their dependents;

$\ddot{u}$ tenants of houses belonging to the Soviets of Workers' Deputies, their family members and their dependents;

$\ddot{u} \quad$ tenants renting residential buildings from persons owning houses on the basis of private property rights, their family members and their dependents.

The Decree of 17 October 1937 stated that the provisions of the right to use residential premises, which clearly define the rights and obligations of the parties, as well as the conse- quences of their violation, should be reflected in written contracts; A written agreement on the right to use the residential building in all houses is concluded with the tenant, the housing office or the tenant.

During the term of the contract, unilateral violation or modification by the housing authorities was prohibited.

The above-mentioned Resolution stated that small houses belonging to local soviets (not exceeding 60 square meters in size) should be used by individual citizens on the basis of long-term lease agreements concluded for 5 to 10 years on the basis of a standard contract to be approved by the USSR Council of People's Commissars.

A typical contract for the lease of a dwelling house with an area of no more than 60 square meters was approved by the USSR Council of People's Commissars on November 25, 1937 [8].

According to Article 36 of the Resolution "On protection of housing stock and improvement of housing in cities", in houses belonging to individual citizens on the basis of the right to build houses and private property or in houses rented by citizens from local councils, it was allowed to receive rent in the amount not exceeding $20 \%$ of the rent established by law.

The decision also provided that in the case the tenant or his family members regularly demolished the apartment building and common areas, or did not allow other residents to live together in the apartment or room by their own actions, or did not pay the rent within three months, the apartment lease agreement can be terminated through the court.

In a number of cases established by the Decree of 17 October 1937, administrative evictions were allowed without providing housing.

We would like to note that the term "housing legislation" was first reflected in the Resolution "On the protection of the housing stock in cities and the improvement of housing". After creation of the term "housing law" a number of legal scholars began to conduct research on housing law relations. For example, in 1940, a well-known civilist scholar S.I.Asknaziy's book "Soviet Housing Law" was published in Moscow, which deals with the management of the housing stock and the distribution of housing [9]. 
Plenum of the Supreme Court of the USSR adopted Decision No " $46 / 23 / \mathrm{u} /$ on December 12, 1940 "On the judicial practice on the application of the decision of the Central Executive Committee of the USSR and the Council of People's Commissars of October 17, 1937" "On protection of housing and improvement of housing in cities". The decision noted that the courts made serious mistakes in implementing the decision of the USSR Central Executive Committee and the Council of People's Commissars of October 17, 1937 "On the protection of housing and improvement of housing in cities" and they underestimate the importance of the struggle to increase the responsibility of tenants for maintenance and to establish strong contractual relations in the field of renting residential buildings. Often, if a tenant or his or her family member is found guilty of systematically demolishing or destroying a home, the courts will reject the eviction claim, and when they are evicted, they are not provided for reimbursement for the damage they have caused to the building. Courts do not always uphold claims for evictions of tenants who deliberately violate the rules of cohabitation when considering evictions of tenants who do not allow other tenants to live together in the same apartment.

In order to create unity in the legislation governing the right of citizens to buy and build individual houses and in accordance with Article 10 of the USSR Constitution, the Presidium of the Supreme Soviet of the USSR issued a decree on August 26, 1948 "On the right of citizens to buy and build individual houses" [10]. The decree stipulated that every citizen of the USSR (male and female) had the right to buy or build a one- or two-storey house with one to five rooms, both in the city and outside the city, on the basis of private property rights. Plots of land are allocated for citizen's indefinite use, both in the city and outside the city, in order to build a private house. To instruct the USSR Council of Ministers to issue a decree on the application of this decision.

On August 26, 1948, the USSR Council of Ministers adopted Resolution No. 3211 "On the Procedure for Applying the Decree of the Presidium of the Supreme Soviet of the USSR of August 26, 1948" On the Right of Citizens to
Acquire and Build Individual Housing". Paragraphs 1-7 of the decision stated:

- To instruct the executive committees of the Council of Workers' Deputies of the country, province, city and district to allocate land plots to citizens, both in cities and outside cities, for the construction of one- or two-storey detached houses with 1 to 5 rooms.

- Land plots for the construction of individual houses are allocated for permanent use at the expense of cities, settlements, the state land fund and the state forest fund, and the houses built on these land plots are the private property of their builders.

- The size of land plots in each case, depending on the size of the house and local conditions, is determined by the executive committees of the provincial, city and district Soviets of Workers' Deputies within the following norms: from 300 to 600 square meters in the city; 700 to 1,200 square meters outside the city.

- Land tax is levied in the amount established by law for the use of land plots.

- Individual houses should be built in areas suitable for this purpose in accordance with the planning and construction projects of cities, suburbs and settlements.

- Individual houses should be built on typical and individual projects. The executive committees of the Council of Local Workers'. Deputies should provide the builders with the necessary standard projects.

- Landscaping of areas, construction of sidewalks within their area, proper maintenance of both the site and adjacent sidewalks and crossings in accordance with the rules established by the decisions of local councils shall be the responsibility of the owners of individual houses.

The Plenum of the Supreme Court of the USSR, by its Decision of 22 January 1954, made some changes to Decision No. 46/23/u of the Plenum of the Supreme Court of the USSR of 12 December 1940, stating that if the court finds that the dwelling is illegal, ie not used for its intended purpose (to turn a residential building into a non-residential building or, conversely, to live in common areas - corridors, kitchens, small warehouses, etc.) they must invalidate the agreements between the tenants and seize the building and evict 


\section{Цивільне, підприсмницьке, господарське та трудове право}

those who use it inappropriately for its intended purpose.

\section{Bibliographic references}

1. Azərbaycan SSR-in Mülki Məcəlləsi (1923cü il). Azərbaycan SSR-in Mülki Məcəlləsi (1964cü il): Bütün əlavə və dəyişikliklər də daxil olmaqla məcəllələrin bərpa edilmiş tam mətnləri. Bakı: Hüquq Yayın Evi, 2013, 540 s. [In Azerbaijani].

2. Qanunlar Külliyyatı, Bakı, 1926, № 5, maddə 129 [In Azerbaijani].

3. Qanunlar Külliyyatı, Bakı, 1926, № 11, maddə 266 [In Azerbaijani].

4. Qanunlar Külliyyatı, Bakı, 1927, № 10, maddə 254 [In Azerbaijani].

5. Qanunlar Külliyyatı, Bakı, 1927, № 12, maddə 299 [In Azerbaijani].

6. Qanunlar Külliyyatı, Bakı, 1929, № 5, maddə 86 [In Azerbaijani].

7. Qanunlar Külliyyatı, Bakı, 1930, № 1, maddə 13 [In Azerbaijani].

8. Собрание Законов СССР, 1937, № 74, статья 361 [in Russian].

9. Аскназий С.И. Советское жилищное право. М.: Юридическое издательство НКЮ CCCP, 1940, 184 c. [in Russian].
The article states that, looking at the history of the development of real estate legislation, we see that in the 20s and 50s of the twentieth century, the legislation of the Union of Soviet Socialist Republics, did not include the division of property into movable and immovable. Thus, the Civil Code of the Azerbaijan SSR, adopted on June 16, 1923 after the establishment of the Soviet power in Azerbaijan, does not contain the terms movable thing or movable property, nor immovable thing and immovable property. However, the abovementioned Code and other normative legal acts adopted at that time, including the Constitution of the Azerbaijan Soviet Socialist Republic of March 14, 1937, reflected issues related to certain types of real estate (land, residential areas, etc.).

Keywords: Law, code, article, institution, property, history.

10. Указ Президиума Верховного Совета СССР от 26 августа 1948 года «О праве граждан на покупку и строительство индивидуальных живых домов». Ведомости Верховного Совета СССР, 1948, № 36 [in Russian]. 